University of Nebraska - Lincoln

DigitalCommons@University of Nebraska - Lincoln

University of Nebraska Press -- Sample Books

and Chapters

University of Nebraska Press

Fall 2010

Telling Children's Stories

Mike Cadden

Follow this and additional works at: https://digitalcommons.unl.edu/unpresssamples

Part of the Arts and Humanities Commons

Cadden, Mike, "Telling Children's Stories" (2010). University of Nebraska Press -- Sample Books and Chapters. 33.

https://digitalcommons.unl.edu/unpresssamples/33

This Article is brought to you for free and open access by the University of Nebraska Press at DigitalCommons@University of Nebraska - Lincoln. It has been accepted for inclusion in University of Nebraska Press -- Sample Books and Chapters by an authorized administrator of DigitalCommons@University of Nebraska - Lincoln. 


\section{Telling Children's Stories}

$-6 e^{2}$ 


\section{Frontiers of Narrative}

SERIES EDITOR

David Herman

Ohio State University 


\section{Telling Children's Stories}

Narrative Theory and Children's Literature

EDITED BY MIKE CADDEN

$\operatorname{ag} 20$

University of Nebraska Press | Lincoln and London 
(c) 2010 by the Board of Regents of the University of Nebraska. Illustrations in chapter 5 are reprinted from Time to Get Out of the Bath, Shirley by John Burningham. Published by Random House. Used with permission. Illustrations in chapter 7 are reprinted from The Red Tree by Shaun Tan. Published by Lothian Children's Books. Used with permission. All rights reserved. Manufactured in the United States of America.@

Library of Congress Cataloging-in-Publication Data

Telling children's stories: narrative theory and children's literature / edited by Mike Cadden. p. $\mathrm{cm}$. - (Frontiers of narrative)

Includes bibliographical references and index. ISBN 978-o-8032-1568-9 (pbk.: alk. paper)

1. Children's literature-History and criticism. 2. Narration (Rhetoric) 3. Children's literatureAuthorship. I. Cadden, Michael.

PN1009.A1T445 $2010 \quad 809$ '.89282-dc22

2010018219

Set in Tribute and Minion Pro by Kim Essman.

Designed by A. Shahan. 


\section{Contents}

Introduction vii

MIKE CADDEN

PART ONE GENRE TEMPLATES AND TRANSFORMATIONS

1 Telling Old Tales Newly: Intertextuality in Young Adult Fiction for Girls 3

ELISABETH ROSE GRUNER

2 Familiarity Breeds a Following: Transcending the Formulaic in the Snicket Series 22 DANIELLE RUSSELL

3 The Power of Secrets: Backwards Construction and the Children's Detective Story 44 CHRIS MCGEE

PART TWO APPROACHES TO THE PICTURE BOOK

4 Focalization in Children's Picture Books: Who Sees in Words and Pictures? 65 ANGELA YANNICOPOULOU

5 No Consonance, No Consolation: John Burningham's Time to Get Out of the Bath, Shirley 86 MAGDALENA SIKORSKA

6 Telling the Story, Breaking the Boundaries: Metafiction and the Enhancement of Children's Literary Development in The Bravest Ever Bear and The Story of the Falling Star 100 ALEXANDRA LEWIS 
7 Perceiving The Red Tree: Narrative Repair, Writerly Metaphor, and Sensible Anarchy 120 ANDREA SCHWENKE WYILE

8 Now Playing: Silent Cinema and Picture-Book Montage 140 NATHALIE OP DE BEECK

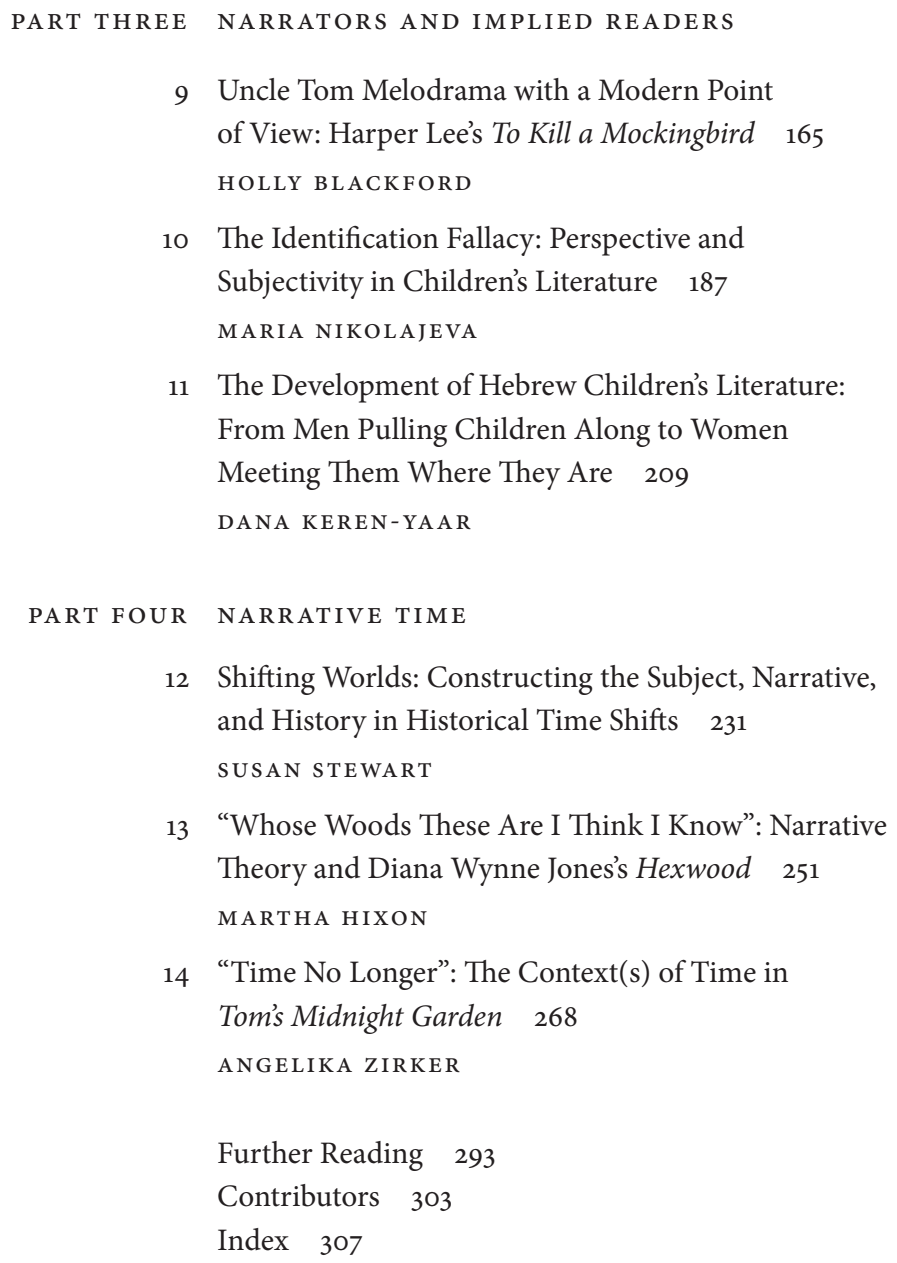

12 Shifting Worlds: Constructing the Subject, Narrative, and History in Historical Time Shifts 231

13 "Whose Woods These Are I Think I Know": Narrative Theory and Diana Wynne Jones's Hexwood 251 MARTHA HIXON

14 "Time No Longer": The Context(s) of Time in Tom's Midnight Garden 268

ANGELIKA ZIRKER

Further Reading 293

Contributors 303

Index 307 


\title{
Introduction
}

\author{
MIKE CADDEN
}

To introduce this collection of essays on narrative theory and children's literature, I'd like your indulgence as I discuss one area of narrative theory that takes on different implications when discussed in the context of children's literature: the peritext. It's my way of justifying the intersection of narratology and literature for the young right from the start. The second part of the introduction is more conventional: an explanation of the development of the study of children's literature as an academic field, the development of its literary theory, and the relatively recent embrace of narratology. You'll find particular introductions to the collected essays themselves at the beginning of each part.

\section{The Peritext and Children's Literature}

"This is [...] the part where the author tells why the book exists and why the reader might want to read it. And you can skip it if you're in a hurry."-Laura Schlitz.

These are the first words of the foreword to the 2008 Newbery Medal-winning book. ${ }^{1}$ It seems like a good way to introduce a book about narrative theory and children's literature. An editor's introduction to any book about narrative approaches should begin with some self-consciousness about two separate matters: the role of the peritext and the nature of the implied reader. ${ }^{2}$ In fact both matters are discussed in this volume by several essayists. 
The peritext is a good example of an aspect of narrative theory of special interest to those who study children's literature exactly because it has so much to do with assumptions about the implied reader, itself a central concern in children's literature.

As I was taking my kids to school one day, my then sevenyear-old daughter interrupted her reading of Barbie's Fairytopia to ask, "Dad, what does "I-n-t-r-o-d-u-"

"It spells 'Introduction."

"What's that?"

"Well, that's the part of the book that explains things that you might want to know before you read so you'll understand what you read better."

"Oh ... I guess I won't read it, then."

"Why not?"

"I don't want to spoil it."

And so she didn't. Harry Shaw points out that for child readers, "being coerced into playing a role [as a reader] is different from being forced into an actual state of belief" (210). And it seems clear that my daughter was neither coerced by the impetus of the peritext nor a believer in its authority. She read about the Barbieclone fairies of Fairytopia without a concern in the world for what the nice person who wrote the introduction might have wanted her to know. Children learn early, whether through experience or the hasty page-turning by tired parents reading to them, the place of the peritext-both literally and figuratively.

A. A. Milne, creator of Winnie-the-Pooh, begins his second book of children's poetry with this meta-introduction: "This bit which I am writing now, called Introduction, is really the er-h'r'm of the book, and I have put it in, partly so as not to take you by surprise, and partly because, having started, I can't do without it now. There are some very clever writers who say that it is quite easy not to have an er-h'r'm, but I don't agree with them. I think it is much easier not to have all the rest of the book." And so it is.

In an age of irony, the peritext also gives us a sense of the implied reader of the book. Do children understand and appreciate irony? Is it there for the adults' consumption while the chil- 
dren are meant to get other things? A playful peritext is often the measure of what the author and the publisher in combination believe to be true about the audience(s) of a children's book. Perhaps the most famous jab at the introduction in a children's book is that from Jon Scieszka and Lane Smith's popular picture-book parody of folktales, The Stinky Cheese Man and Other Fairly Stupid Tales, which ends with the lines: "In fact, you should definitely go read the stories now, because the rest of this introduction just kind of goes on and on and doesn't really say anything. I stuck it on the end here so it would fill up the page and make it look like I really knew what I was talking about. So stop now. I mean it. Quit reading. Turn the page. If you read this last sentence, it won't tell you anything," and is signed by the character narrator Jack, of "Up the Hill, Fairy Tale Forest." Suspicions about introductions are confirmed for adults and raised for children.

Gérard Genette argues that the introduction is supposed to do a couple of things, after all: get the book read and get it read properly. By whom? Consider implications for children's literature. Who reads the introduction in the bookstore? Parents, librarians, teachers, and other concerned adults. So often in children's literature the introduction is pitched specifically to one or many adult audiences. When this is the use of the children's book introduction, it further mediates the experience for the child. Someone is screening. This is Mom and Dad reading the warning label. "Okay, not too much propyl gallate, potassium bromate, or red dye number three. Enjoy." In the case of the children's book, the implied audience for the introduction is then often different from the implied audience of the text itself. So it sells the book to the parents but not yet to the child. The parent, as an extra layer of mediation, must now sell the book to Junior. In this way the children's book publisher gets to the kids through the parents.

We could argue that the peritext of a children's book is meant for adults (copyright, publication house, introduction, etc.); such an argument implies that children get used to ignoring the packaging information and continue to do so even when they become the adult readers for whom, ostensibly, this material exists. This 
often is accomplished early on after a child accuses an adult of skipping pages. "Hey, you're skipping!"

"This isn't part of the story."

"Read it!"

"Okay, 'All rights reserved. No part of this book may be reproduced, transmitted, or stored in an information retrieval system in any form or..."'

"You can skip it."

Sometimes, children are given information in introductions that is necessary in order to understand what's to come. The introduction to Chris Van Allsburg's picture book The Mysteries of Harris Burdick tells us that the individual pictures accompanied by a title and an opening line of story (for example, "Archie Smith, Boy Wonder" is followed by "A tiny voice asked, 'Is he the one?") were left with a publisher by a mysterious man named Harris Burdick who promised to return with the rest of the stories the next day, but he never returned. For a reader to begin with the first picture and page of scant writing only to turn the page to an unrelated picture and written text would likely result in confusion. Here, then, the implied reader of Van Allsburg's book is assumed to be a reader of introductions. Black and White, an innovative (and much glossed) picture book by David Macaulay, warns us by way of a note on the title page that we need to consider the relationship between words and pictures-consider that they may or may not fit together as a story. In this way we are given a frame of mind, a challenge, a speculation that help us enter the story. Those who have breezed past this introduction haven't the same advice about "use." And if you don't read the prologue to Sylvia Engdahl's Enchantress from the Stars, a science fiction novel marketed to young adults, you won't know that the teenaged character narrator is writing the story from three points of view for her field report as a planetary observer. That book's prologue is now preceded by a foreword from Lois Lowry on the book's importance. This might invite the reader to skip the multiple thresholds leading into the "real" story, leaving her to wonder why everyone sure seems to like this teenager character! 
Well, that's because she's the one putting words in their mouths. But who knew?

Note that in some of these cases, we have some narrators or authors addressing the primary implied readership of the text, not just the purchasers (adults). This, we could argue, blurs the lines between what is text and what is peritext as well as those texts that address both children and adults simultaneously, either separately or together. Consider Lemony Snicket's The Bad Beginning, the first book of the Series of Unfortunate Events. In this book we have a fiction, a deception, from the title page onward: we are told that the book is authored by "Lemony Snicket" (David Handler employs the name as not only a character narrator but, at first, as an alias). Snicket warns us (who?) in second-person address on the book's first page, "If you are interested in stories with happy endings, you would be better off reading some other book. In this book, not only is there no happy ending, there is no happy beginning, and very few happy things in the middle. [.. . ] I'm sorry to tell you this, but that is how the story goes." From the beginning there is a fascinating admission of unhappiness, which is meant to intrigue the implied reader, presumably the middle school child who has had her fill of happy endings and would like a bit of dark humor. The back of the book, another peritextual feature, promises/warns us that this is an "extremely unpleasant" book. So, the opening lines serve as our introduction and both sells with darkness and accurately prepares us for what we're in for. So, too, Avi's Something Upstairs contains an introductory "Author's Explanation"-a bit different as a heading, and playing up the idea of providing necessary information. In this "explanation," Avi tells of meeting with young Kenny Huldorf and (after dreading meeting another adoring fan) becomes absolutely fascinated with his story (implication: you will be as well). Avi claims only to be the mediary: He says for starters, "This is the strangest story I've ever heard" and finishes with "This is it. His story. My writing. I think it's true." The last line, despite being confusing about what is true-the story or Avi's writing-is one last appeal to our fascination. It's not only fascinating; it's pos- 
sibly true. It has that well-used appeal to our hope that the story has some connection to reality: "The story you are about to see is true. The names have been changed to protect the innocent." Here, though, Avi (played by himself) is using his own author(ity) to get his young readers to half-believe that he's telling the truth. A famous author wouldn't steer me wrong! And it's stranger than anything this professional storyteller has ever heard. This calls us back to the Van Allsburg ruse: the mystery presumably makes it more interesting than the story or pictures in their own right. Roald Dahl employs a similar move in his fictional introduction to The Witches. In the opening "A Note about Witches," our narrator tells us that "in fairy-tales, witches always wear silly black hats and black cloaks, and they ride on broomsticks. But this is not a fairy-tale. This is about REAL Witches. [...] And if you know about these [survival tips], if you remember them always, then you might just possibly manage to escape from being squelched before you are very much older."

Each of these last three books promises a bit of fascinating darkness, a thrill of the supernatural or horribly natural, the anticipation of truth, and the line between textuality and peritextuality is effectively blurred, especially as young readers almost surely equate the voice of the speaker of the opening lines with that of the author. These are not like those introductions implied to be read by adult screeners of books that go something like "This book has just gobs of educational and morally uplifting information and nothing in the slightest that could lead to your child practicing Satanism, Animal Sacrifice, or Bad Hygiene." These fictional introductions directed to the child, on the other hand, provide an early taste of the subject and, no small matter, of the style or voice of the book, as is the case with The Mysteries of Harris Burdick and Enchantress from the Stars.

This discussion of something as simple as the strategic use of the introduction in children's books is meant to illustrate just how some aspects of narrative take on greater (or at least different) significance when we consider the special context of children's literature. There are other obvious critical issues particular to children and their literature that, like peritextual ele- 
ments themselves, append to the text and have been and should continue to be the focus of study, including the use of cover art in the marketing of young adult literature (see Yampbell). This discussion of introductions to children's books in this volume's introduction-offered as a metaperitextual gesture-provides some reasons why we should care about narrative approaches to children's and young adult stories. You are the implied reader of this volume if you care about either narrative approaches or children's stories, though I hope we are successful in implying that the intersection of narrative approaches and children's stories is an important and revealing one.

\section{Children's Literature: History, \\ Genre, and Narratology}

This volume, as part of the Frontiers of Narrative series, offers a consideration of the ways in which narrative matters in children's literature-a genre that isn't exactly a new area of study, though from time to time a scholar "discovers" this scholarly area hidden in plain view. It is a "frontier," perhaps, as both a rediscovered reading pleasure for adults and an undiscovered scholarly world to critics who suddenly find themselves with young children. It surprises some that children's and young adult literature has much to offer the world of critical theory. In this arena the canon war is still being waged.

It's important to consider the development of children's literature as an area of study and the development of its narrative theory in particular. Because the development of theory is relatively recent and the development of the literary field unusual, we enjoy right now an explosion of theory in general and of narrative theory in particular (the dates of texts in "Further Reading" point to this phenomenon). There is much ready to be done both in studying narrative theory comparatively across adult and children's literature and considering the poetics of children's literature itself.

Children's literature is a bit unusual as a genre and an academic discipline. Not only is the study often claimed by one of three 
disciplinary camps in different departments (though it is sometimes practiced by more than one department on more fortunate campuses), it is a bit unusual within the course construction models of most departments of English. Courses tend to be delineated by textuality (genres like poetry, short fiction, the novel), subtextuality (travel literature, monsters, and other themes), or contextuality (the literature of a place or a people-the demographics of race, gender, ethnicity, nation). As a course and genre defined in a contextual way, children's literature is, to quote a favorite "Sesame Street" song, "not like the others." While women's literature, Caribbean literature, and British literature of the nineteenth century are contextually designed, they tend to focus on the producers rather than (or in addition to) the consumers of the texts. Here is where implied audience becomes a necessary consideration to those studying children's literature whether they care about narratology or not. It is the reader alone for whom the genre is defined-a reader almost certainly not present either in children's literature classes or in the ranks of those authors on the syllabus and certainly not among the scholars.

In order to understand the trajectory of theory in the study of children's literature and of children's literature theory itself, we should consider the context of academic discipline. The study of children's literature is a balkanized business. The "English" areas of college composition and women's literature made huge strides in the 1980s, in large part because they didn't remain relegated to departments of English. Composition studies, though somewhat estranged from university departments of communications and rhetoric, became cross-disciplinary as it expanded into programs of writing across the curriculum, writing in the disciplines, and it gained respect among faculty across the university campus through the development of writing-intensive courses. Women's literature became one part of a larger disciplinary movement of women's studies, inviting students and faculty in other disciplines into the literature classroom; women's literature became part of courses in sociology, history, and more. In short, both of these other "English" areas won academic respect and support 
and strengthened their stake in departments of English by being relevant across campus. The recent movement in childhood or children's studies, begun by Brooklyn College almost twenty years ago, offers some hope here; there are still very few such programs across the country, however. The study of children's literature has been similar to the study of communications divided between English and journalism more than it has been like the successful disciplinary juggernaut of writing across the disciplines. Children's literature is usually relegated to one of three disciplinary houses: education, library science, or English. If its study exists simultaneously in two or three of those departments, it has been coincidental or contentious rather than cooperative; unlike in departments of library science and education, however, scholars of children's literature in English departments have had to justify their business to their departmental colleagues. Rod McGillis explains some implications of the phenomenon:

Because the texts upon which critics of children's literature write are for children, [.. .] children's literature critics find themselves looked upon with some suspicion by academic critics who work on mainstream literature. From the other end, the teachers, librarians, parents, and children who read children's literature look with some suspicion on those who spend their lives intellectualizing these ostensibly simple books. This double estranging of the children's literature critic puts him or her in an awkward position: wanting to speak to those both within and without the academy and finding, if not hostility, then at least disrespect from both groups. (17)

Children's literature was taught wherever it was established first, and the department that had original ownership rarely saw it pop up in other departments, regardless of the shift in critical emphasis. The idiosyncrasy of this can be even more complicated: at my own undergraduate institution, Virginia Tech, the adolescent literature class is found in the education department, while 
children's literature is taught in the English department. To add to this problem for the literary study of children's literature, very few doctoral institutions have children's literature courses in their English departments, making graduate study of children's literature from a literary standpoint inconvenient at best. Then, too, those graduating with an emphasis in children's literature have many fewer departments of English available to employ them.

This phenomenon has had an impact on the development of children's literature as an area of literary study. Maria Nikolajeva notes that "the principal difference between research on children's literature and general literary criticism [...] is that children's literature has from the very beginning been related to pedagogics" (Children's Literature Comes of Age 3), and so much of the early critical work in children's literature was in the context of literacy. Jill May argued in 1991 for a literary approach to children's literature in education departments. Herself an education professor, May bemoaned the attitude that there was "no purpose for the study of literature in the elementary classroom other than as a means to teach other concepts in the curriculum" and having reading instruction identified as the only use for books (275). Maria Nikolajeva, writing in 1996, notes that it has been "only in the past ten years that the literary aspects of children's literature have been noticed and appreciated and subjected to contemporary literary theory and methods" (Children's Literature Comes of Age 4), and even then in many fewer American and British universities for the reasons discussed earlier. Nine years later, Nikolajeva still felt the need to comment in the preface to her new textbook, "This book is not about teaching literature to children, but about becoming critical adult readers of children's literature" (Aesthetic Approaches v).

As you might imagine, then, apologia has been a healthy strand of critical writing in children's literature. A 1973 New York Times article by Children's Literature Association founding member Francelia Butler accuses otherwise broad-minded humanists of being embarrassed by discussing children's books. In 1978 Mary Agnes Taylor pitched a plea in the journal of the Association of 
Departments of English to "convince [her] audience that children's literature belongs in college English Departments" (17). In the introduction to a 1985 special issue of Studies in the Literary Imagination on narrative approaches to children's literature, editor Hugh Keenan writes that "such a linking of modern critical approaches and children's literature calls for some explanation" (1). Did it? Does it yet? Keenan goes on to say about the journal issue, "As the analyses of these essays show, children's literature is not simple. It is often more sophisticated than we have allowed" (2). Peter Neumeyer argued in 1987 that "children's literature as an academic field is about as childish as pediatrics" (146). A cautious Peter Hunt writes in 1990 that he "would like to think that the cause of children's literature is now won, and that its academic status is secure, but to very many readers it will be a new and questionable discipline, and its critical development needs to be laid out" ("New Directions" 7). The strand is wider and longer than this, but this sampling shows that hand-wringing over children's literature's status as a literature has been, and in some quarters continues to be, a preoccupation with those of us who write about the genre. Added to the dilemma of status is the problem of identity, for all along while arguments are being made about developing courses and even programs in children's literature, critics ask, "Just what is children's literature?"

There is the tradition in children's literature circles to ask, "What is children's literature?" and then proceed at great length to avoid answering the question-a phenomenon seen in criticism of other beset genres such as fantasy and science fiction. ${ }^{3}$ Sue Gannon considers the task of defining children's literature "likely to be the work of a lifetime" (59) and, paraphrasing Clifford Geertz in a different context, believes the "'progress' toward the answers we seek is [.. . ] marked less by a perfection of consensus than by a refinement of the debate" (69). The question is obviously important, perhaps more for the way it leads to decisions about critical approaches to children's literature than for any answer that might be offered. The greatest distinction is that between degree and kind. Those who believe that children's literature is different by 
various degrees from literature for adults draw more on the work of critics in other fields to point to the marked tendencies of children's literature to do more or less in using different structures or emphasizing different subtexts. Those who see children's literature as different in kind in relationship to literature for adults spend their time arguing about that which makes the genre unique. An important moment in theorizing children's literature-especially through narrative theory-was the fall 1985 issue of Studies in the Literary Imagination, edited by Hugh Keenan. The issue's topic was "Narrative Theory and Children's Literature," and the issue featured the field's most influential scholars weighing in on the narrative nature of the genre. The editor notes with enthusiasm that through narrative theory "there promised to be critical ways of answering the perennial question: how is children's literature different from other literatures?" (1). In the same issue Peter Hunt expresses concern that to decontextualize children's books-to treat them just as any book-necessarily means that we ignore what makes children's books unique: "the intended or implied or actual readers" ("Necessary Misreadings" 108). Six years later he argues more forcefully that "what we must look for is a children'sliterature-specific theory" (Criticism, Theory 192), one that he calls "childist," a sympathetic reading from the perspective of the implied audience parallel to feminist reading. Perry Nodelman, in contrast, muses, "We may conclude that the similarity of good children's books to each other makes children's fiction different from adult fiction-different enough that it requires its own interpretive approach. [.. .] Or we may reach quite a different, and, to my mind, more sensible conclusion - that, in fact, children's fiction is less significantly a special sort of fiction than a serious challenge to conventional ideas about interpretation and distinctiveness" (6). Both scholars were struggling along with the field itself regarding the best literary approaches to an emerging academic discipline.

Of course, there are the critics who suggest that children's literature doesn't exist at all because it includes in its audience-or restricts its audience to-adults. Critics such as Jacqueline Rose 
and Jack Zipes are influential in debates about children's literature because by arguing against the genre's existence, they inspire a great deal of response. Employing psychoanalytical theory, Rose argues that children's literature is an impossible category because the audience is a construct created by adult writers, publishers, and caregivers; a special issue of Children's Literature Quarterly devoted to considering the effect of her book The Case of Peter Pan twenty-five years after its publication has recently been announced. In chapter 3 of his book Sticks and Stones, "Why Children's Literature Does Not Exist," Zipes turns to Marxism to claim that "children' and 'childhood' are social constructs that have been determined by socioeconomic conditions and have different meanings for different cultures. Thus the concept of children's literature is also imaginary" (40). I'm not sure that people in the textile industry would argue that children's clothing doesn't exist because of the changes over the centuries to fashion that reflect our own adult designs on "childhood" and children. The categories of children's clothes and books are each contested sites driven by both adult and children's own desires and uses. In any case, the critics who deny the existence of children's literature provide an important theoretical position on defining the genre.

It wasn't until the eighties that children's literature achieved this sort of theoretical and critical self-consciousness. In the "Further Reading" section of this volume, you'll note that the texts that could be considered narrative theory published before the mid-1980s are very few in number. Jill May observes that "although children's literature [...] always had a theoretical base for study, reading stances that concentrate on literary aspects of children's literature did not evolve until the 1970s" (23), though Peter Hunt notes that "anti-intellectualism has produced much so-called criticism which is simply impressionistic and populist in the worst sense" (Criticism, Theory 5). In a 1970 article Paul Heins, long-time editor of the Horn Book Magazine, muses whether "the time has come for the criticism of children's literature to be more conscious than ever before of its existence-and better 
still of its function" (402). It would be a decade or more before such critical and theoretical self-consciousness would become common. Beverly Lyon Clark tells in her award-winning Kiddie Lit: The Cultural Construction of Children's Literature in America the story of her own development in the 1970s as a children's literature scholar and notes that she was "not impressed by the scholarship [she] then started to read. Much of it seemed to focus on bibliotherapy, providing lists of books [...] . Most of the books seemed to be annotated bibliographies in paragraph form" (xi).

The trajectory of narrative theory in the study of children's literature has been coincidental with the development of theory in the genre, as the question of structure and poetics necessarily follows the self-conscious criticism that Paul Heins asked for in 1970. The years 1984-85 saw the first journal issue devoted to narrative theory in children's literature-a special issue of Studies in the Literary Imagination. In the same year, in a Children's Literature Quarterly special section devoted to narrative theory and children's literature, Hunt writes what was still possible to write in 1984: "Critical theory may not seem to have much to do with children and books" ("Narrative Theory" 191). As he made the case for narrative theory in the eighties and early nineties, others have provided newer and sophisticated narrative approaches, most notably Barbara Wall, Zohar Shavit, Maria Nikolajeva, Robyn McCallum, Leona Fisher, and Andrea Schwenke Wyile. Deb Thacker, as late as 2000 , writes that she is surprised that notable theorists, in an age of intertextuality, haven't seen the value of children's literature to their theories, such as Barthes's notion of jouissance, Fish's interpretive communities, Eco's open and closed texts, and more (1). Maria Nikolajeva writes in her 2005 Aesthetics of Children's Literature that "other important theories, such as narrative theory and carnival theory, have been used only sporadically" (vi), so influential critics continue to call for more theorizing about children's literature as a genre. And so there is still much work to be done, and we hope that this volume will help spur more work in children's literature using narrative approaches-and of work in narrative theory using children's literature. 
There are many opportunities for studying children's and young adult literatures using a narratological approach, as the "Further Reading" section at the end of this book suggests. Beyond the four elements covered in this volume-genre, picture books, narrators and implied readers, and narrative time-there are other important categories of particular interest. Within the larger category of character study, the phenomenon of anthropomorphism is prevalent and important in children's books as it is in no other genre; it is often seen as a subject of identification as well as a distancing strategy. The age of a character narrator is an important consideration in terms of marketing and implied readers. Children's and young adult literature critics note plot patterns that tend to correspond to genre (for example, Odyssean patterns in children's fiction and in young adult literature the "apocalyptic" plot defined by Frank Kermode). While both intertextuality and metafiction have been common features of postmodernism generally, in children's literature they take on new significance when we consider the degree to which we assume children are supposed to recognize aesthetic features or other tales. And the study of ethical narration is an obvious area of interest in children's and young adult literatures as a necessary complement to the subject of censorship. Dorothy Hale observes that "the more deeply [she] looked into new ethical theories of literature, the more [she] came to notice the central role played by one literary genre in particular ... novels" (189). To my mind the end of that sentence could easily read "children's literature." For as ethically revelatory as the novel has always been, no literary genre has ever taught us more about a culture and its values than the literature published for a society's children. Diachronic studies of the narrative features of series fiction remain to be written, and the relatively new explosion in verse novels (some epistolary, some not) is a great opportunity for research. These verse novels for young readers experiment with polyphony, voice, and focalization in interesting ways. A good deal has been written lately about crossover writing (a book that crosses over readerships in various ways and over time) and writers (like Rudyard Kipling, Gertrude Stein, Maria 
Edgeworth, and Ursula K. Le Guin), but the poetics of crossover writing is another field with scholarly potential.

This volume is intended to be of use to a variety of audiences. The essays assembled here offer beginning students access to key developments in the field without making too many assumptions about prior knowledge; thus, technical terms have been kept to a minimum, and where they are used, they are always defined immediately-either in the text or in a footnote. At the same time, the arguments put forward in the essays are nuanced and sophisticated, exploring issues that continue to be relevant for more-advanced students as well as faculty specialists. This collection would be appropriate for students in undergraduate theory classes in which the children's books in question can be read as subjects of study. It would be ideal as a course text in a narrative theory class. It is also intended for those interested in children's literature in a variety of disciplinary realities both in and outside literature departments who have come to think about children's books in a different way.

Although the volume divides the study of narrative in the context of children's and young adult literatures into four parts, the parts speak to one another across those categories. They're hardly mutually exclusive. As matters of genre come into play in the discussion of narrative time, the picture book is considered in terms of narration and focalization-and many issues such as metatextuality, voice, and the implied reader appear over and over again. The collection could be used in such a way that many different juxtapositions of readings could be designed for course use.

It's my hope that this volume can acquaint narratologists with the richness and depth of children's literature and conversely acquaint children's literature scholars and critics with the usefulness of narrative approaches for analyzing this unique genre. The volume will also alert faculty specialists as well as advanced undergraduate and graduate students in each of these areas to the merits of the other.

A. A. Milne ends his introduction to Winnie-the-Pooh with the observation that "perhaps the best thing to do is to stop writ-

xxii Introduction 
ing Introductions and get on with the book." That sounds like a good idea.

\section{Notes}

1. The John Newbery Medal, given by the American Library Association, recognizes the most distinguished contribution to American literature for children of the previous year. It is considered by many to be the most prestigious award in American children's literature.

2. Genette defines the "peritext" as that part of the book "materially appended to the text within the same volume" (344). It includes features such as the title of the book, the author's name, the dedication, the table of contents, prefaces and afterwords, even covers. Genette divides paratext into two classes: the peritext and the epitext. The peritext refers to all kinds of paratext within the book; the epitext refers to paratexts outside the volume, such as reviews and other commentary on the text.

The "implied reader" is the reader for whom a text seems meant. It is the ideal audience for a text as implied by a text's subject matter, linguistic and stylistic choices, and other elements that imply a best recipient.

For more commentary on the peritext in children's literature, see Higonnet, Yampbell, Sipe and McGuire, and Jenkins. Peter Hunt makes interesting claims for the ways children remember a book, including a response to the peritextual element of book-cover color as the means for categorizing or remembering a book (Criticism, Theory 67).

3. In the Children's Literature Association's first presidential address, Jon Stott asked, "What is children's literature?" (May 25, 1978). We've been attempting to answer him in the thirty years since.

4. In the first issue of the Quarterly devoted to the subject (1990), Hunt-the volume's editor-talks about the important potential of a narrative approach to children's literature, although he laments that, "unfortunately, much narrative theory has tended to the descriptive and classificatory, processes that are not always enlightening" (46). It would be thirteen years until a second narrative-theory special issue of Children's Literature Association Quarterly would appear.

\section{Works Cited}

Avi. Something Upstairs: A Tale of Ghosts. New York: Avon, 1990. Butler, Francelia. Book review. New York Times 6 May 1973. Clark, Beverly Lyon. Kiddie Lit: The Cultural Construction of Children's

Mike Cadden xxiii 
Literature in America. Baltimore: Johns Hopkins University Press, 2003.

Dahl, Roald. The Witches. New York: Farrar, 1983.

Engdahl, Sylvia. Enchantress from the Stars. New York: Atheneum, 1970.

Gannon, Susan. "Perspectives on Children's Literature: An Overview."

Teaching Children's Literature: Issues, Pedagogy, Resources. Ed. Glenn Sadler. New York: MLA, 1992. 59-71.

Genette, Gérard. Paratexts: Thresholds of Interpretation. Trans. Jane E. Lewin. Cambridge: Cambridge University Press, 1997.

Hale, Dorothy J. "Fiction as Restriction: Self-Binding in New Ethical Theories of the Novel." Narrative 15.2 (May 2007): 187-206.

Heins, Paul. "Out on a Limb with the Critics." Children and Literature: Views and Reviews. Ed. Virginia Haviland. Glenview IL: Scott, 1973. 400-07.

Higonnet, Margaret. "The Playground of the Peritext." Children's Literature Association Quarterly 15.2 (Summer 1990): 47-49.

Hunt, Peter. Criticism, Theory, and Children's Literature. Cambridge m A: Blackwell, 1991.

_ . "Narrative Theory and Children's Literature." Children's Literature Association Quarterly 9.4 (1984-85): 191-94.

_ . "Necessary Misreadings: Directions in Narrative Theory for Children's Literature." Studies in the Literary Imagination 18.2 (Fall 1985): 107-21.

_. "New Directions in Narrative Theory." Children's Literature Association Quarterly 15.2 (1990): 46-47.

Jenkins, Elwyn. "Reading outside the Lines: Peritext and Authenticity in South African Children's Books." The Lion and the Unicorn 25.1 (Jan. 2001): 115-27.

Keenan, Hugh T. "Editor's Comment." Studies in the Literary Imagination 18.2 (Fall 1985): 1-2.

Kermode, Frank. The Sense of an Ending: Studies in the Theory of Fiction. Oxford: Oxford University Press, 1966.

Macaulay, David. Black and White. New York: Houghton, 1990.

May, Jill P. Children's Literature and Critical Theory. New York: Oxford University Press, 1995.

McGillis, Roderick. The Nimble Reader: Literary Theory and Children's Literature. New York: Twayne, 1996.

Milne, A. A. The House at Pooh Corner. 1928. London: Methuen, 1965.

Neumeyer, Peter. "Children's Literature in the English Department." Children's Literature Association Quarterly 12.3 (1987): 146-50.

xxiv Introduction 
Nikolajeva, Maria. Aesthetic Approaches to Children's Literature. Lanham MD: Scarecrow, 2005.

- Children's Literature Comes of Age: Toward a New Aesthetic. New York: Garland, 1996.

Nodelman, Perry. "Interpretation and the Apparent Sameness of Children's Novels." Studies in the Literary Imagination 18.2 (Fall 1985): 5-20.

Rose, Jacqueline. The Case of Peter Pan: Or the Impossibility of Children's Fiction. New York: Macmillan, 1984.

Schlitz, Laura Amy. Good Masters! Sweet Ladies! Voices from a Medieval Village. Illus. Robert Byrd. Cambridge m A: Candlewick, 2007.

Scieszka, Jon, and Lane Smith. The Stinky Cheese Man and Other Fairly Stupid Tales. New York: Viking Penguin, 1992.

Shaw, Harry E. "Making Readers." Narrative 15.2 (May 2007): 207-21.

Sipe, Lawrence, and Caroline McGuire. "Picture Book Endpapers:

Resources for Literary and Aesthetic Interpretation." Children's Literature in Education 37.4 (Dec. 2006): 291-304.

Snicket, Lemony. The Bad Beginning. New York: HarperCollins, 1999.

Taylor, Mary Agnes. "Children's Literature and the English Department." ADE Bulletin 56 (Feb. 1978): 17-19.

Thacker, Deborah. "Disdain or Ignorance? Literary Theory and the Absence of Children's Literature." The Lion and the Unicorn 24.1 (Jan. 2000): 1-17.

Van Allsburg, Chris. The Mysteries of Harris Burdick. New York: Houghton, 1984 .

Yampbell, Cat. "Judging a Book by Its Cover: Publishing Trends in Young Adult Literature." The Lion and the Unicorn 29.3 (Sept. 2005): 348-72.

Zipes, Jack. Sticks and Stones: The Troublesome Success of Children's Literature from Slovenly Peter to Harry Potter. New York: Routledge, 2001. 